\title{
AQUATIC FUNGI AND IMPORTANT FUNGAL DISEASES OF FARIMED FISH
}

\author{
Mehwish Faheem ${ }^{1}$, Maria Latif ${ }^{2}$, Iram Liaqat ${ }^{1}$, Riaz Hussain $^{3}$ and Tauseef-ur-Rehman ${ }^{4}$ \\ 'Department of Zoology, GC University Lahore, Pakistan \\ ${ }^{2}$ Fisheries Research and Training Institute, Manawan Lahore, Pakistan \\ ${ }^{3}$ Department of Pathology, The Islamia University of Bahawalpur, Pakistan \\ ${ }_{4}$ Department of Parasitology, The Islamia University of Bahawalpur, Pakistan \\ *Corresponding author: mehwishfaheem@gcu.edu.pk
}

\section{INTRODUCTION}

Fisheries and aquaculture are the most important sources of animal protein and this sector provides employment to around 31.1 million people globally (Gozlan and Britton 2014). Disease outbreaks in animals, including fish, result in significant economic losses. Many infectious agents like bacteria, virus, fungi and parasites cause diseases in fish. Bacterial and fungal diseases are two top reasons for economic losses in aquaculture (Gonçalves and Gagnon 2011). Fungal diseases are becoming one of the most important emerging problems with increasing incidences, mainly because of their wide geographic range and increase in virulence (Loo 2009; Peeler et al. 2010). Many infectious fungi have now been discovered and many of them have found new hosts (Kim and Harvell 2004; Frick et al. 2010). The exact reason behind the increase spread and virulence of fungi is unclear, however, their resilient nature (Mitchell et al. 2008), opportunist behavior (Fisher et al. 2012), active and long life cycle (Andreou et al. 2009) and spread of invasive and infectious species can be the major contributing factors (Gozlan et al. 2010). Outbreaks of fungal infections are increasing rapidly and are responsible for local extinctions of many species, including bees, amphibians, turtles and other reptiles, bats and fish (Gozlan et al. 2005, 2009; Fisher et al. 2009; Frick et al. 2010; Ratnieks and Carreck 2010; Sarmiento-Ramírez et al. 2010). Fish are more susceptible to fungus and fungus like microorganisms. Despite the huge mortalities of fish species caused by fungal and fungal like pathogens, it is difficult to detect infections primarily due to lack of direct observations and also due to absence of external signs and symptoms (Gozlan et al. 2010; Gozlan and Britton 2014). Hence, a healthy fish without external signs may be carrier of fungal pathogens that may result in massive infection and high mortalities (Andreou et al. 2011). Fungi causing infections in fish are mostly saprophytic that get nourishment from dead and decaying organic matter. The saprophytic fungus infects almost all stages of fish, including eggs, fry, fingerling and adult stage. Fungi may be the secondary invaders, as they attack the host that is already injured mechanically or suffering from an infection other than fungi (Roberts 2012).

This chapter focuses on true fungal pathogens of fish and also highlights the diseases caused by fungi and fungal like pathogens and their impact on fish populations. Moreover, the detection methods and their limitations have also been discussed.

\section{Fungi and their Classification}

Fungi are eukaryotes and like other living organisms, they are identified on the basis of their morphological characters like shape, structure and behavioral properties. In early 1990's, stains were used to identify fungi but with advancement of technology, various other methods like pattern of nutrient utilization, growth temperature and rate testes were used for fungal identification (Raja et al. 2017).

Traditionally, fungi are grouped as single independent cell i.e. yeast or fungi that have thread like hyphae called molds or hyphal fungi. Asexual reproduction is common in fungi. Sexual reproduction also occurs in almost all fungi, except deuteromycetes previously known as fungi imperfecti. Sexual reproduction results in the formation of spores and spore bearing hyphae, called as mycelium. Spores have different names, such as zygospores produced by fungi belonging to Zygomycota. Motile diploid spores are produced by Chytridiomycota, basidiospores are produced within basidia by fungi belonging to Basidiomycota, while ascospores are produced within asci of fungi belonging to Ascomycota (Wyatt et al. 2013).

Traditionally, fungi were classified into:

$\begin{array}{ll}\text { i. } & \text { Ascomycota } \\ \text { ii. } & \text { Basidiomycota } \\ \text { iii. } & \text { Zygomycetes } \\ \text { iv. } & \text { Chytrids }\end{array}$

This classification has now been revised. Fungi now include true fungi, fungus like organisms and molds. True fungi are most diverse group of organisms classified into six phyla, 35 classes and 129 orders (Fig. 1).

Chytrids are most primitive and simple form of true fungi. Their cell wall contains chitin, except for one group that contains both cellulose and chitin. Most members of phylum Chytridiomycota are unicellular but some hyphal forms also exist, which have aseptate hyphae. Spores produced by chytrids are diploid with a single flagellum.

Phylum Zygomycota, also known as conjugated fungi, includes bread molds which propagate on bread, fruit and vegetables. The important genus of this phylum is Rhizopus. Asexual reproduction is through sporangiospores, while sexual reproduction is through formation of diploid zygospores that undergo meiosis and develop into new organisms.

Most of true known fungi belong to phylum Ascomycota, also known as sac fungi. Members of this phylum are 
economically important. The phylum includes morels and truffles, which are used as food, for example yeast is used in baking fermentation and brewing, Aspergillus oryzae is used to produce sake, while some members are parasitic. Asexual reproduction is through conidiospores, while sexual reproduction is through ascospores that are produced in fruiting body called ascocarp.

Basidiomycota, also known as club fungi, are easily recognizable under light microscope due to the presence of club shaped fruiting body called basidia. Members of Basidiomycota are mushrooms, smuts and rusts.

Deuteromycete, also known as fungi imperfecti and belonging to Deuteromycota, are the only fungi that reproduce asexually. They are closest to ascomycetes and the mycelium spread on substrate like a mold. Members of this phylum include some economically important fungi. Some are used in cheese making, others are used to make antibiotics (like penicillium), while some produce toxic metabolites like mycotoxin producing fungi, aspergillus.

Most of the fungal species responsible for infection in fish belong to Ascomycota (Hibbett et al. 2007) and some belong to phylum Zygomycota orMesomycetozoea (Glockling et al. 2013). Various species in these phyla are opportunist and not exclusive to fish. Some cause infections in plants e.g., Phoma herbarum and Penicillium corylophilum, while others cause infections in immunosuppressed humans e.g., Ochroconis humicola and Exaphiala xenobiota.

Fungal like parasites belong to oomycote, also known as water molds, and include more than 500 species (Beakes et al. 2012). Oomycetes resemble morphologically to fungi, as they have filamentous growth and similar feeding behavior. The main difference is the composition of cell wall. The cell wall of fungi is made of chitin, while that of oomycetes is made of glycan and other cellulosic compounds. Moreover, the nuclei of fungi are haploid, while those of oomycetes are diploid. Important genera of order Saprolegniales that cause infections in fish are Saprolegnia, Aphanomyces, Achlya and some are from genus Pythium. Two most important species are Saprolegnia parasitica and Aphanomyces invadans, causing infections in 12 and 42 fish species, respectively.

Hyphochytriomycota are fungus like zoospore producing organisms. They are most closely related to algal groups. They have been previously classified with Protiscta and Protoctists (Whittaker 1962; Margulis 1990).

Slime molds are other fungus like organisms and have two main groups; cellular slime molds and plasmodial slime molds. Cellular slime molds (Dictyosteliomycota) are singular ameboid cells but on getting a signal they start aggregating to form a giant amoeba or slug that starts acting as single cell. Plasmodial slime molds (Myxomycota) are formed when many flagellated cells fuse together. The resulting giant mold is a big bag of cytoplasm with thousands of nuclei (Volk 2013). Plasmodiophoromycota are endoparasites and don't have cell walls in their assimilative states.
Important fungal disease in aquaculture

In order to reduce environmental footprints, increase biosecurity and to have better control on culture conditions, aquaculture practices are shifting towards intensive aquaculture. High stocking densities in intensive aquaculture systems may lead to stress in fish and increase incidents of disease outbreaks (Peeler et al. 2010). Fungal spores are present everywhere, and poor water quality and stress in fish are two main factors that contribute to the disease outbreak in aquaculture system. Other factors contributing to fungal infections are; poor hygiene, low immunity and high amount of decomposing organic matter at the pond bottom (Verma 2008). Important fungal diseases and their respective hosts are listed in Table 1.

\section{Saprolegniasis}

Saprolegniasis, commonly known as cotton wool disease, is caused by Saprolegnia sp. (Saprolegnia parasitica and Saprolegnia diclina), belonging to family Saprolegniaceae (Table 1). These two species are most commonly associated with saprolegniasis infection and, hence often written as $S$. parasitica-diclina complex (Rezinciuc et al. 2014). Saprolegnia is a filamentous fungus with branched and aseptate mycelium. It is a classical opportunist saprophytic fungus that feeds on dead decaying matter.

Saprolegniasis is the most common infection of freshwater and estuarine fish present in warm tropical water. Temperature plays an important role in saprolegniasis infections. Chances of infection increase as water temperature decreases below the physiological end point for fish (Roberts 2012). This may be due to the fact that many oomycetes are active in cold water. Severity of infection increases when water temperature hits $15^{\circ} \mathrm{C}$, resulting in high fish mortality which is also called winter kill. Stress in fish resulting from high water temperature also results in disease outbreak.

Unfertilized fish eggs are infected with Saprolegnia and infection spreads to fertilized and healthy eggs, resulting in the complete loss of the batch.

\section{Diagnosis}

Saprolegniasis is characterized by the presence of white cottony growth on the fish. Skin tissue is the main infected organ. However, eyes and gills may also be infected with the fungus. Saprolegnia, a water mold, is a fungus like pathogen not a true fungus (Latijnhouwers et al. 2003). The hyphae of saprolegnia are aseptate, while hyphae of true fungi are septate. The common diagnosis is based on the presence of cotton like growth on gills and skin. Microscopic observation of aseptate and broad hyphae that can be stained with hematoxylin and eosin and also with Gomori methenamine silver stain is also an indication of saprolegnia infection (Noga 2010). Fish appear lethargic, stop responding to external stimuli, show loss of balance and die. 


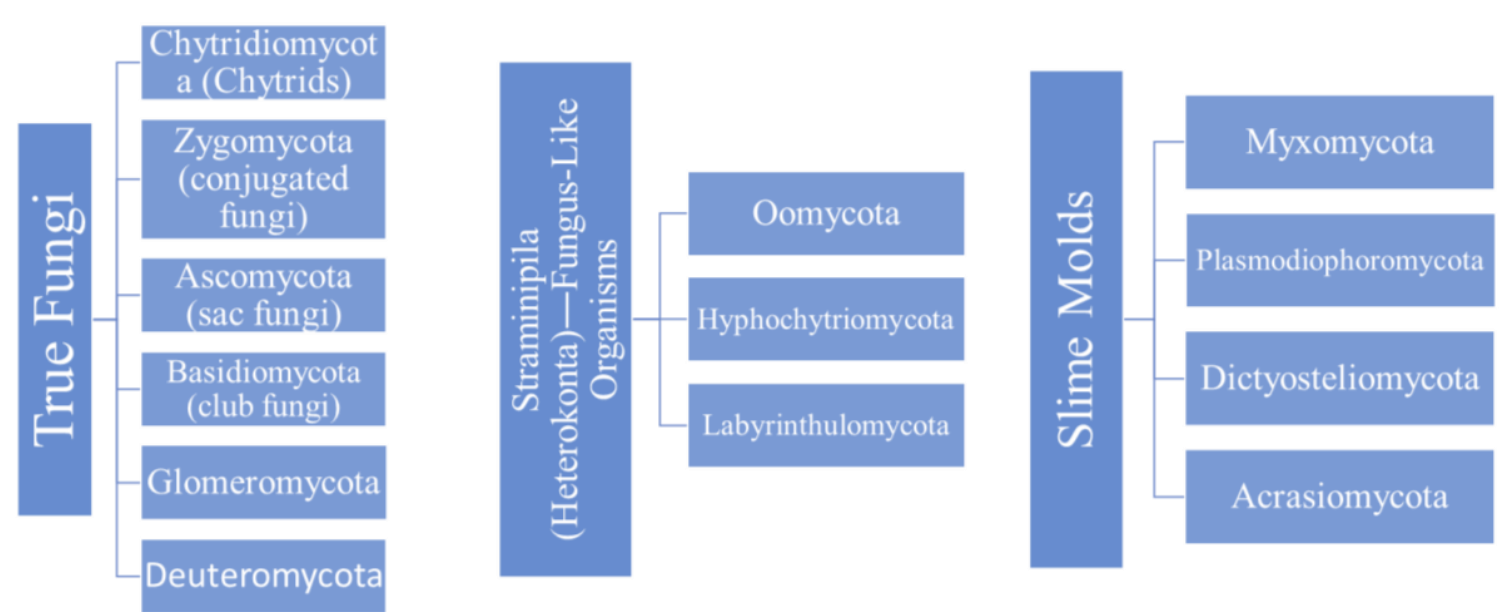

Figure 1: Classification of fungi based on scheme presented by Deacon (2006).

Table 1: List of fungal pathogens of fish and their reported hosts

\begin{tabular}{|c|c|c|c|}
\hline & Fungal species & Order & Reported host \\
\hline \multirow[t]{5}{*}{ True Fungi } & Exophiala angulospora & \multirow[t]{3}{*}{ Chaetothyriales } & Atlantic cod \\
\hline & Exophiala pisciphila & & Zebrafish shark \\
\hline & Exophiala xenobiotica & & Striped jack \\
\hline & Paecilomyces lilacinus & \multirow[t]{2}{*}{ Eurotiales } & African catfish, Nile tilapia \\
\hline & Penicillium corylophilum & & Red snapper \\
\hline \multirow{8}{*}{$\begin{array}{l}\text { Fungus } \\
\text { Like } \\
\text { Organisms }\end{array}$} & Dermocystidium cyprini & \multirow[t]{6}{*}{ Dermocystida } & Common carp, Eurasian ruffe \\
\hline & Dermocystidium fennicum & & European perch \\
\hline & Dermocystidium koi & & Common carp \\
\hline & Dermocystidium percae & & European perch \\
\hline & Dermocystidium branchiale & & Brown trout, Arctic char \\
\hline & Sphaerothecum destruens & & Common carp, common bream, sunbleak, rainbow trout, Atlantic salmon \\
\hline & Ichthyophonus hoferi & Ichthyophonida & $\begin{array}{l}\text { speckled sanddab, Atlantic herring, surf smelt, coho salmon, chinook } \\
\text { salmon, rainbow trout, brown trout }\end{array}$ \\
\hline & Ichthyophonus irregularis & & yellowtail flounder \\
\hline \multirow[t]{22}{*}{ Oomycetes } & Achlya bisexualis & \multirow[t]{17}{*}{ Saprolegniales } & Grey mullet \\
\hline & Achlya racemose & & Pejerrey \\
\hline & Achlya americana & & African catfish, Nile tilapia \\
\hline & Achlya oblongata & & European white fish \\
\hline & Achlya ambisexualis & & Rainbow trout \\
\hline & Aphanomyces frigidophilus & & Brown trout, European whitefish \\
\hline & Aphanomyces invadans & & European eel, barbs, African catfish, channel catfish, Channa sp, common \\
\hline & Aphanomyces irregularis & & carp, Indian major carps, rainbow trout, grey mullet, breams \\
\hline & Aphanomyces laevis & & African catfish, Nile tilapia \\
\hline & Saprolegnia brachydanis & & Zebrafish \\
\hline & Saprolegnia diclina & & Persian sturgeon, brown trout, red drum \\
\hline & Saprolegnia shikotsuensis & & European white fish \\
\hline & Saprolegnia ferax & & Brown trout, rainbow trout, pejerry, goldfish \\
\hline & Saprolegnia furcate & & Brown trout \\
\hline & Saprolegnia hypogyana & & Rainbow trout, brown trout \\
\hline & Saprolegnia parasitica & & Rainbow trout, brown trout, Channel catfish, Atlantic salmon, masu salmon \\
\hline & Saprolegnia polymorpha & & Common carp \\
\hline & Saprolegnia salmonis & \multirow{5}{*}{ Pythiales } & White spotted char, brown trout, rainbow trout, red salmon, masu salmon \\
\hline & Pythium aquatile & & European white fish \\
\hline & Pythium pulchrum & & \\
\hline & Pythium thalassium & & \\
\hline & Pythium torulosum & & \\
\hline
\end{tabular}

\section{Treatment and control}

Once infection is started, it is usually progressive and terminal. Treatment of saprolegnia has gained much attention and many chemicals have been tested against fungal growth in vitro. External disinfectants are usually used but most of the legally approved disinfectants have limited effect. While many fungal diseases are difficult to treat, the best preventive measurements are maintaining good water quality parameters, husbandry practices, improved feeding and avoiding overcrowding. Localized treatment of wound with $0.1 \%$ malachite green or bath treatment (0.2 ppm for an hour or indefinite with $0.1 \mathrm{ppm}$ ) is usually recommended. Use of malachite green is 
prohibited in many countries due to its mutagenic and teratogenic effects. Environment with high salt concentration limits saprolegnia growth, that's why the infection is rare in marine fish. Bath treatment with sodium chloride (30 g/l for half hour or $1-3 \mathrm{~g} / \mathrm{l}$ for indefinite time) is helpful in treating saprolegnia infections. Bath treatment with potassium permanganate for 30-9o minutes at the rate of $1 \mathrm{~g}$ per 100 liters of water is effective. Other treatments include bathing with copper sulphate for 10-30 minutes (5-10 g per 100 liters of water) or with 10-25 g sodium hydroxide for 10-20 minutes (Dorcas et al. 2015).

\section{Branchiomycosis}

Branchiomycosis, commonly known as gill rot, is another important fungal infection of fish. Similar to saprolegnia, two species of Branchiomyces are responsible for gill rot. Branchiomyces demigrans causes infection in bass (striped and largemouth bass), pike and tench, while $B$. sanguinis causes infection in carps.

Environmental stressors, like low dissolve oxygen, low $\mathrm{pH}$ (5.8-6.5) and high algal blooms, are responsible for the disease outbreak. Fungal spores are carried through detritus on pond bottom and dispersed through pond water. Fungus can grow at water temperature range of 14$35^{\circ} \mathrm{C}$ but grows fast when water temperature ranges from $25-32^{\circ} \mathrm{C}$.

As the name indicates, this fungus causes pathology of gills. Both species of Branchiomyces cause ischemia and thrombosis of gills and gills becomes marbled or striated in appearance. Infection of $B$. sanguinis is restricted to blood vessels of gills, while that of $B$. demigrans spreads from blood vessels to the lumen. Fish becomes lethargic and swim near water surface to gulp air (El-Sayed 2020).

\section{Diagnosis}

Externally, the gills of infected fish may appear pale with brown area because of hemorrhage, or grayish due ischemia. As the infection progresses, the narcotic gill tissue may slough off and fish might get a secondary infection of saprolegnia.

Fungal hyphae penetrate in the gills and obstruct the blood vessels, resulting in necrosis. As gill damage progresses, fish mortality starts due to anorexia. Disease outbreak results suddenly with a mass mortality up to $50 \%$ in $2-4$ days.

Histopathology and wet mount analysis of the lesions are used to diagnose branchiomyces infection. Hyphae penetrated deep in the gill lamellae are characteristic of the infection (Yanong 2003).

\section{Treatment and control}

Branchiomycosis infection can be treated with $0.3 \mathrm{ppm}$ of malachite green for 24 hours. One hour exposure of 1-4 ppm of benzalkonium is also used for the treatment. Common chemicals used for treatment are 3-5\% sodium chloride or $100 \mathrm{ppm}$ copper sulphate for 10-30 minutes.
Reducing water temperature below $20^{\circ} \mathrm{C}$ and reducing organic load of the pond is helpful in slowing fungal growth. Treatment with formalin can also help in lowering mortalities. All the water holding sites, raceways and aquaria must be dried and treated with calcium oxide (quick lime) (Noga 2010).

\section{Ichthyophoniasis}

Fungal infection 'Ichthyophoniasis' is caused by fungus Ichthyophonus. This species infects cod, herrings, groupers and trout.

\section{Diagnosis}

Clinical signs and symptoms usually vary according to the fish species. Infected fish show erratic swimming pattern, swollen belly, anemia along with loss of appetite. Internally, swelling of vital organs like liver, kidneys and spleen are reported with white nodules. Such white nodules are also apparent in the muscles of infected fish.

\section{Treatment}

No specific treatment is reported for the affected fish.

\section{Epizootic Ulcerative Syndrome (EUS)}

Aphanomyces invadans or A. piscicida is the causative agent of Epizootic Ulcerative Syndrome (EUS). This fungus causes the disease in more than 30 freshwater species. Catfishes and snakeheads are most commonly infected.

\section{Diagnosis}

Infected fish show loss of appetite and swim below surface water or with head protruding out of the water surface. Occasionally, fish may show jerky movements and appear very hyper active. Darker skin discoloration, along with ulcerative lesions on the body, is indicative of EUS. Lesions may be small with rosacea appearance and restricted only to sides of jaw and head or deep lesions may be present anywhere on the body.

When the disease progresses, lesions become very deep and visceral organs or the vertebral column may be exposed. Tail erosion is also common in infected fish. Internally, the fungus penetrates fish muscles, resulting in inflammation and severe tissue necrosis. Mortality occurs when fungal hyphae reachcranium and kidneys.

\section{Treatment and control}

Outbreaks of EUS usually occur in cold weather from December to February. Therefore, special care should be taken in these months to avoid the disease outbreaks. Disinfecting the pond and water supplies and reducing fish stocking density can also help in limiting the disease outbreaks.

Treatment of infected fish with chelated copper compounds, like $5 \mathrm{ppm}$ of control or with $0.1 \mathrm{ppm}$ of malachite green, may be helpful in treating the EUS infection. 
Current detection techniques and future perspective

Pathogens are traditionally characterized by their morphological, serological and phenotypic properties. Lesions are normally developed in fish after infection. Swab sampling from the area of lesion, isolating and culturing of the causative agent is the usual practice to identify the pathogens and to understand the disease etiology and host-parasite relationship. However, the procedure is time consuming with a chance of contamination and requires technical expertise.

Grocott's methanamine silver stain is used to stain the fungal species isolated from the lesions. With advancement of science, fluorescent probes have been designed which are species specific and used for direct visualization of the infectious agent. Immunofluorescent identification of Aphanomyces invadans and A. astaci is made using a monoclonal antibody, MAb 3gJC9, specific for antigen involved in pathogenicity of these species (Miles 2003). This approach has proved to be better over traditional staining identification of the fungus. Moreover, with the use of immunofluorescent detection, infections are detected at very early stages. Fluorescent in situ hybridization (FISH) is also used to identify fungal infections (Sosa et al. 2007a\&b). Improvements in molecular techniques have led to a more accurate identification of fungal pathogens compared to previously used staining methods. Species, sub species and strains level identification is now possible with the use of polymerase chain reaction (PCR) (Phadee et al. 2004; Tsui et al. 2011). Use of similar DNA fragments to identify the species offers benefits of understanding phylogenetic relationship among species. Primers specified for $18 \mathrm{~S}$ rRNA are used to identify large number of fungal species, as well as mesomycotozoans; however, oomycetes are more accurately identified using Internal Transcribed Sequence 1 (ITS1).

There is a huge gap of availability of genetic data present in public data bases, such as Genbank. Therefore, it is need of hour that all the regional cases of disease outbreak should be identified at molecular level, sequenced and data be submitted to public data bases, so that more information may become available. Detection of species using $18 \mathrm{~S}$ rRNA and strains using ITS 1 will provides a better knowledge of virulent pathogens. Also, the molecular data will resolve phylogenetic ambiguities among fungal species.

\section{Conclusion}

In conclusion, the chapter described the important fungal and fungus like pathogens of farmed fish. It highlighted the existing knowledge about diagnosis and treatment of fungal diseases and also pointed the gaps that need to be addressed in order to prevent epizootic diseases. Most of the fungal infections in aquaculture appear when fish is under stress. Proper farm management is the key to avoid infections and reducing economic loss. Due to the lack of specific treatments for fungal diseases, generalized treatment strategies are opted to control fungal diseases.
Chemicals used for treatment of fungal diseases are considered hazardous for human health and are therefore banned in many countries including USA and EU. Maintaining proper water quality, feeding a balanced diet and proper handling of fish can avoid stressful conditions, leading to less disease outbreaks. Recently, use of medicinal plants and herbs in aquaculture has contributed to successful control of fungal infections. Use of plantbased additives are cost effective and eco-friendly, however, further research is required to explore the potential of using plant and plant based materials to control fungal diseases in aquaculture.

\section{REFERENCES}

Andreou D et al., 2009. Temperature influence on production and longevity of Sphaerothecum destruens zoospores. Journal of Parasitology 95: 1539-1541.

Andreou D et al., 2011. Sphaerothecum destruens pathology in cyprinids. Diseases of Aquatic Organisms 95: 145-151.

Beakes GW et al., 2012. The evolutionary phylogeny of the oomycete "fungi." Protoplasma 249: 3-19.

Deacon J, 2006. Fungal Biology. $4^{\text {th }}$ Edition. Blackwell Publishing Ltd, Oxford, UK.

Dorcas YS et al., 2015. Biology and diseases of amphibians. In: Fox JG, Anderson LC, Otto GM, Pritchett-Corning KR, Whary MT (editors), Laboratory Animal Medicine, Third Edition. Academic Press, New York, USA; PP: 931-965.

El-Sayed AFM, 2020. Stress and diseases. In: El-Sayed, AFM (editor), Tilapia Culture, Second Edition. Academic Press, New York, USA; pp: 205-243,

Fisher MC et al., 2012. Emerging fungal threats to animal, plant and ecosystem health. Nature 484: 186-194.

Fisher MC et al., 2009. Global emergence of Batrachochytrium dendrobatidis andamphibian chytridiomycosis in space, time, and host. Annual Review of Microbiology 63: 291-310.

Frick WF et al., 2010. An emerging disease causes regional population collapse of a common North American bat species. Science 329: 679-682.

Glockling SL et al., 2013. Phylogenetic interpretations and ecological potentials of the Mesomycetozoea (Ichthyosporea). Fungal Ecology 6: 237-247.

Gonçalves AA and Gagnon GA, 2011. Ozone application in recirculating aquaculture system: An overview, ozone: science \& engineering. The Journal of the International Ozone Association 33: 345-367.

Gozlan RE et al., 2005. Disease threats on European fish. Nature 435: 1045-1046.

Gozlan et al., 2009. Characterisation and geographical isolation of Sphaerothecum destruens in Europe. International Journal of Parasitology 39: 1055-1058.

Gozlan et al., 2010. Pan-continental invasion of Pseudorasbora parva: Towards a better understanding of freshwater fish invasions. Fish and Fisheries 11: 315340.

Gozlan RE and Britton JR, 2014. Sustainable freshwater fisheries: The search for workable solutions In: Craig J 
(editor), Freshwater Fisheries Ecology. WileyBlackwell Publishing.

Hibbett et al., 2007. A higher-level phylogenetic classification of the Fungi. Mycological Research 111: 509-547.

Kim K and Harvell CD, 2004. The rise and fall of a six-year coral-fungal epizootic. The American Naturalist 164: $\mathrm{S}_{52}-\mathrm{S}_{3}$.

Latijnhouwers et al., 2003. Oomycetes and fungi: Similar weaponry to attack plants. Trends in Microbiology 11: 462-469.

Loo JA, 2009. Ecological impacts of non-indigenous invasive fungi as forest pathogens. Biological Invasions 11: 81-96.

Margulis L, 1990. Kingdom Animalia: The zoological malaise from a microbial perspective. American Zoologist 30: 861-875.

Miles DJC, 2003. Immunofluorescence of the epizootic ulcerative syndrome pathogen, Aphanomyces invadans, using a monoclonal antibody. Diseases of Aquatic Organisms 55: 77-84.

Mitchell et al., 2008. Persistence of the emerging pathogen Batrachochytrium dendrobatidis outside the amphibian host greatly increases the probability of host extinction. Proceedings of the Royal Society B: Biological Sciences 275: 329-334.

Noga EJ, 2010. Fish disease diagnosis and treatment. 2nd Edition. Wiley-Blackwell Publishing, New York, USA.

Peeler et al., 2010. Non-native aquatic animals introductions have driven disease emergence in Europe. Biological Invasions 13: 1291-1303.

Phadee P et al., 2004. Detection and identification of fishpathogenic Aphanomyces piscicida using polymerase chain reaction (PCR) with species-specific primers. Journal of Aquatic Animal Health 16: 220-230.

Raja et al., 2017. Fungal identification using molecular tools: A primer for the natural products research community. Journal of Natural Products 80: 756-770.
Ratnieks FLW and Carreck NL, 2010. Clarity on honey bee collapse? Science 327: 152-153.

Rezinciuc et al., 2014. Molecular identification of a bronopol tolerant strain of Saprolegnia australis causing egg and fry mortality in farmed brown trout, Salmo trutta. Fungal Biology. 118: 591-600

Roberts RJ, 2012. Fish pathology. 4th Edition. Wiley Blackwell, New York, USA.

Sarmiento-Ramírez et al., 2010. Fusarium solani is responsible for mass mortalities in nests of loggerhead sea turtle, Caretta caretta, in Boavista, Cape Verde. FEMS Microbiology Letters 312: 192-200.

Sosa ER, 2007a. Pathogenicity studies with the fungi Aphanomyces invadans, Achlya bisexualis, and Phialemonium dimorphosporum: Induction of skin ulcers in striped mullet. Journal of Aquatic Animal Health 19: 41-48.

Sosa ER, 2007b. Aphanomyces invadans and ulcerative mycosis in estuarine and freshwater fish in Florida. Journal of Aquatic Animal Health 19: 14-26.

Tsui CKM, 2011. Molecular techniques for pathogen identification and fungus detection in the environment. IMA Fungus 2: 177-189.

Verma V, 2008. Fungus disease in fish, diagnosis and treatment. Veterinary World 1: 62.

Volk TJ, 2013. Fungi. In: Levin SA (editor), Encyclopedia of Biodiversity, Second Edition. Academic Press, New York, USA; pp: 624-640.

Whittaker RH, 1962. Classification of natural communities. Botanical Review 28: 1-239.

Wyatt TT et al., 2013. Fungal spores for dispersion in space and time. In: Sariaslani $S$ and Gadd GM (editors), Advances in Applied Microbiology. Academic Press, New York, USA; 85: 43-91.

Yanong RPE, 2003. Fungal diseases of fish. Veterinary Clinics: Exotic Animal Practice 6(2): 377-400. 